Єрешко Ю.О.

канд. економ. наук, доиент

Національний технічний університет Украӥни «КПI»

Фрідман Р.

Національний технічний університет Украӥни «КПІ»

Мілько І.B.

канд. економ. наук

Харківський начіональний економічний університет ім. С. Кузнеия

\title{
ПРИНЦИПИ, РОЛЬ ТА ПЕРСПЕКТИВИ БОРГОВОГО ФІНАНСУВАННЯ В УКРАЇНI
}

\section{ПРИНЦИПЫ, РОЛЬ И ПЕРСПЕКТИВЫ ДОЛГОВОГО ФИНАНСИРОВАНИЯ В УКРАИНЕ}

\section{PRINCIPLES, ROLE AND PROSPECTS OF DEBT FINANCING IN UKRAINE}

У статті досліджені ряд теоретико-методологічних та прикладних положень щчодо використання боргових інструментів у фінансуванні компаній. Узагальненні теоретичні основи механізму залучення зовнішніх запозичень на фінансовому ринку Украӥни. Систематизовані основні характеристики інструментів боргового фінансування, щьо застосовуються в прочесі прийняття рішення щзодо інвестування, зокрема банківських кредитів, корпоративних облігацій $і$ лізингу. Виявлені особливості використання боргових інструментів на вітчизняному ринку та уточнено практичні рекомендації щодо їх застосування за сучасного стану економіки.

Досліджено методи боргового фінансування, використовувані українськими компаніями. Здійснено порівняння джерел фінансування для компаній-емітентів на вітчизняному фондовому ринку. Розглянуто особливості функиіонування сегменту корпоративних облігацій на ФБ ПФТС. Досліджено найбільші за розмірами випуски облігаиій підприємствами реального сектору, які відбулися у 2014 році. Було проаналізовано високодохідні корпоративні облігаџії великих українських компаній та були визначені основні причини значного відхилення значень купону та дохідності до погамення для кожного емітента.

На основі даних про емісії облігащій банків на ФБ ПФТС у 2014 рочуі було зроблено висновки про роль фінансових установ на організованому ринку, зокрема ПФТС.

Ключові слова: боргове фінансування, фондова біржа, підприємство-емітент, корпоративні облігації, купонна ставка, кредитний рейтинг.

В статье исследованы ряд теоретико-методологических и прикладных положений по использованию долговых инструментов в финансировании компаний. Обобщены теоретические основы механизма привлечения внешних заимствований на финансовом рынке Украины. Систематизированы основные характеристики инструментов долгового финансирования, применяемые в процессе принятия решения по инвестированию в частности банковских кредитов, корпоративных облигащий и лизинга. Выявлены особенности использования долговых инструментов на отечественном рынке и уточнены практические рекомендации к их применению в условиях украинской экономики. 
Исследовань методы долгового финансирования, которые используют украинские компании. Проведено сравнение источников финансирования для компаний-эмитентов на отечественном фондовом рынке. Рассмотрены особенности функиионирования сегмента корпоративных облигаиий на ФБ ПФТС. Исследованы самые большие по размерам выпуски облигачий предприятиями реального сектора, которые состоялись в 2014 году. Были проанализированы высокодоходные корпоративные облигащии крупных украинских компаний и определены основные причины значительного отклонения значений купона $и$ доходности к погашению для каждого эмитента.

На основе данных об эмиссии облигаџий банков на ФБ ПФТС в 2014 году были сделань выводы о роли финансовых учреждений на организованном рынке, в частности ПФТС.

Ключевые слова: долговое финансирование, фондовая биржа, предприятие-эмитент, корпоративные облигации, купонная ставка, кредитный рейтинг.

In the paper there was explored the number of significant theoretic, methodological and practical issues associated with using debt to fund companies. There were generalized the theoretical foundations the external borrowing mechanism in the financial market of Ukraine. The main characteristics of debt financing instruments used in making investment decisions including bank loans, corporate bonds and leasing were systematized.

The features of using the debt instruments in the domestic market have been revealed and the practical recommendations of their application looking back on an economy situation were refined.

The methods of debt financing, used by Ukrainian companies were analyzed. There is given a comparison of sources of financing for the issuing companies in the domestic stock market. The features of operation segment of corporate bonds FB PFTC were considered.

There were analyzed the high-yield corporate bonds of major Ukrainian companies and the main reasons of a significant values deviation for each issuer's coupon and yield to maturity were determined.

Based on the issue of banks' bonds PFTS Stock Exchange in 2014 there was concluded on the role of financial institutions in the organized market, in particular the PFTS.

Keywords: debt financing, stock-market, corporate issuer, corporate bonds, coupon rate, credit rating.

Вступ. В процесі здійснення економічної діяльності господарськими суб'єктами постійної уваги потребує проблема їх фінансового забезпечення, особливо за умов нестачі власних джерел коштів. Вибір вдалих інструментів зовнішнього фінансування дозволяє максимально раціонально та ефективно управляти фінансовою та господарською діяльністю підприємств, не втрачаючи при цьому фінансової стійкості. Останнім часом, все більшої проліферації набуває спрямованість фінансових інвестицій підприємств у різноманітні фондові інструменти. Так, інструменти фондового ринку становлять сьогодні до 80\% загального портфелю фінансового інвестування капіталу підприємства, що визначає необхідність більш детальної їх характеристики [6].

На відміну від ринку акцій, формування якого обумовлювалося динамікою приватизаційних процесів, сегмент корпоративних облігацій, формувався виключно як сфера фінансового забезпечення, тому фактичне 
функціонування ринку почалося у 1996 р. 3 першими випусками облігацій. Проте, і сьогодні даний сегмент фондового ринку є нестабільним та потребує подальшої розробки механізму його ефективного функціонування.

Розвиток ринку облігацій був нерівномірним, оскільки з 1996 p. відбувалися постійні зміни обсягів емісії корпоративних бондів. Так, протягом 1996-2001 рр. характерними були значні коливання розмірів даного ринку, коли щороку тенденції до зростання змінювалися тенденціями до спаду. 32001 року відбувалося практично стабільне зростання ринку облігацій, і в 2007 році було здійснено максимальний обсяг емісії корпоративних бондів у розмірі 44 480,5 млн грн. Починаючи з 2008 р., для даного сегменту фінансового ринку характерним став значний спад [10].

Дослідження проблем боргового фінансування та залучення зовнішніх джерел коштів на сучасному етапі розвітку економічної системи знайшли відображення у працях таких вітчизняних і зарубіжних вчених, як В. Д. Базилевич, О.Д.Василик, В.М.Геєць, А.І. Ігнатюк, І. О. Лютий, С.В. Науменкова, В. М. Опарін, А. М. Поддєрьогін, О.В. Любкіна, В.М. Шелудько, Ю. Брігхем, Р. Брейли, С. Майерс, Ф. Мишкін, Ф. Фабоці та ін.

Однак, зважаючи на сучасну нестабільну стагнаційну економічну ситуацію, ускладнену до того ж переходом економіки України до постіндусріального розвитку та особливостями динаміки реального сектору економіки, потребує подальшого дослідження комплекс теоретикометодологічних узагальнень щодо прийняття рішеннь в процесі вибору i використання боргових інструментів фінансування діяльності підприємств.

Постановка задачі. Мета роботи полягає в обгрунтуванні місця корпоративних облігацій у системі фінансування та визначенні напрямів розвитку сегменту боргових корпоративних інструментів на вітчизняному фінансовому ринку.

Методологія. Теоретичною та методологічною базою дослідження $\epsilon$ система загальнонаукових та спеціальних методів пізнання, а саме: порівняння, синтезу, прогнозування, проекції, моделювання та ін.

Результати дослідження. Підприємства зазвичай здійснюють розміщення емітованих облігацій на організованому (біржовому) та позабіржовому ринку. Станом на початок 2015 р. на фондовому ринку України діяли десять організаторів торгівлі. Варто зазначити, що даний ринок $\epsilon$ доволі консолідованим, оскільки у 2014 р. на три фондові біржі (Перша фондова торговельна система (ПФТС), Українська біржа, «Перспектива») припадало $98,7 \%$ сукупного обсягу торгів на організованому ринку за всіма фінансовими інструментами [5].

На рис. 1 подано структуру первинного організованого ринку корпоративних облігацій у 2014 році. 


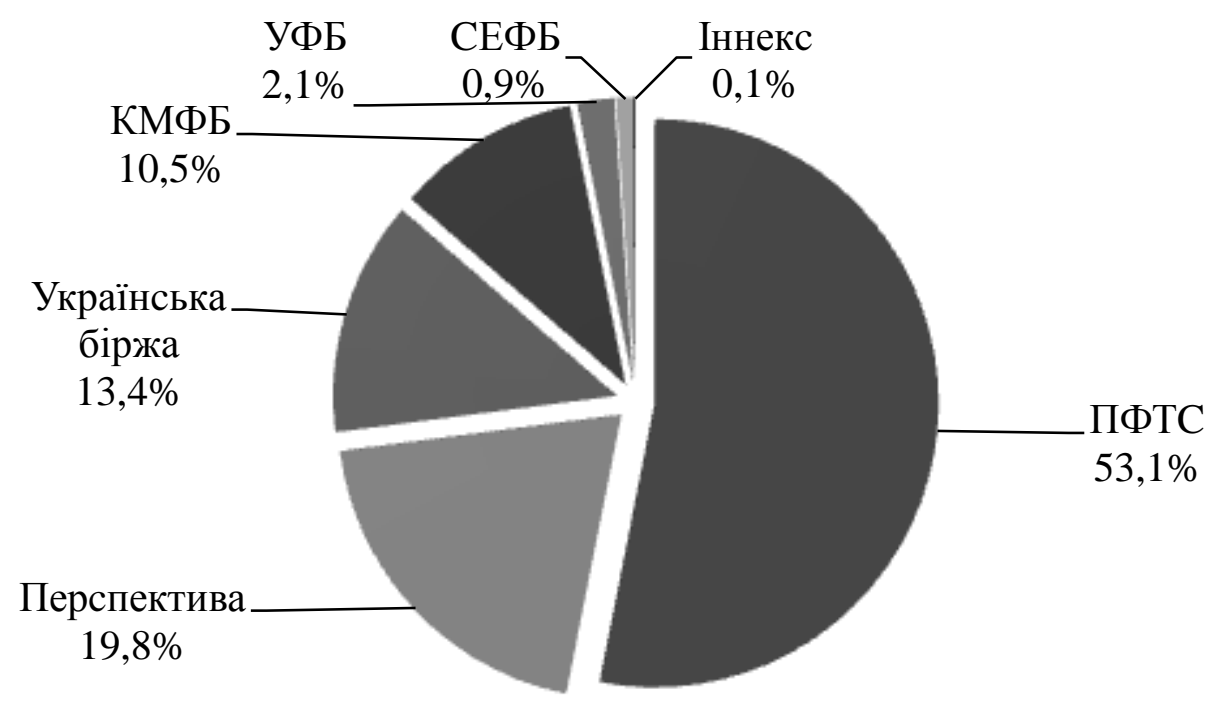

Рис. 1. Розподіл первинного розміщення корпоративних облігацій за організаторами торгів у 2014 році

Джерело: складено автором на основі [5].

Як бачимо з рис. 1, підприємства переважно розміщували власні боргові цінні папери на таких фондових біржах, як ПФТС, Перспектива, Українська біржа та КМФБ (Київська міжнародна фондова біржа). Розглянемо детальніше особливості функціонування сегменту корпоративних облігацій на ФБ ПФТС.

Важливою особливістю ринку у 2014 р. було те, що частка публічних розміщень облігацій підприємств становила $43 \%$ від обсягу зареєстрованих випусків даних цінних паперів [4]. Це обумовлено необхідністю здійснення значних витрат, пов'язаних із залученням посередників на ринку цінних паперів, що сприяє збільшенню витрат даного джерела фінансових ресурсів. Проте, найбільші емісії здійснюються саме на публічному ринку, що дає ряд переваг емітентові від подібного розміщення, про які йшлося вище. Варто зазначити, що розміщення та торгівля корпоративними облігаціями в Україні також здійснюється переважно на фондовій біржі ПФТС, у той час як на трьох 3 десяти бірж (ПФБ, УМВБ,УМФБ) у 2014 р. компанії не проводили розміщення власних облігацій [ 5].

На рис. 2 наведено структуру випущених облігацій, залежно від сфери діяльності підприємства-емітента. 


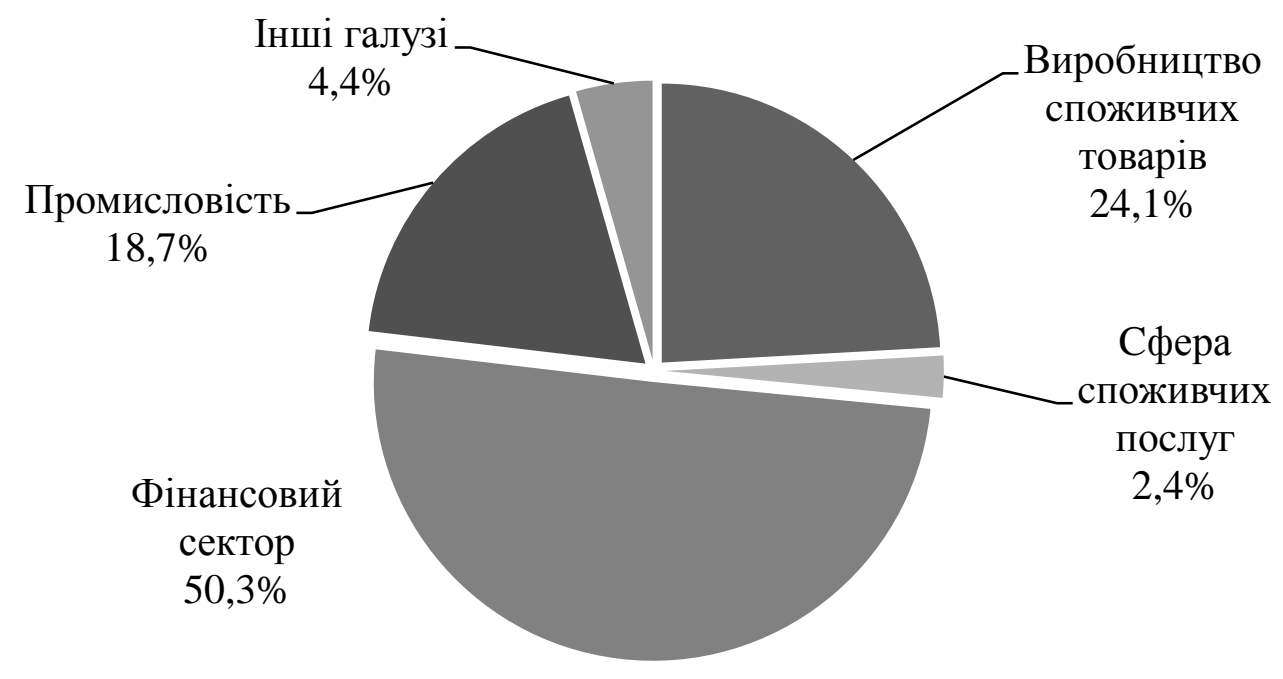

Рис. 2. Розподіл обсягів первинного розміщення корпоративних облігацій на ФБ ПФТС за галузевою приналежністю емітентів станом на 01.01.2015 р.

Джерело: складено автором на основі [5].

За даними рис. 2 можна зробити висновок, що основну частку емітованих на організованому ринку, зокрема ПФТС, здійснюють фінансово-кредитні установи. При цьому, частка банків у загальному обсязі емісій становила $48,2 \%$, серед підприємств фінансового сектору також представлено страхову компанію ПрАТ СК «ДНІПРОІНМЕД» та ТОВ «Український фондовий центр», сумарний обсяг випуску боргових паперів яких становив 2,1\% ринку корпоративних облігацій ПФТС [5].

У табл. 1 наведено найбільші за розмірами випуски облігацій підприємствами реального сектору, які були відбулися у 2014 році.

Таблиця 1

Найбільші емісії облігацій нефінансових компаній на ФБ ПФТС у 2014

році

\begin{tabular}{|c|l|l|c|}
\hline № п/п & \multicolumn{1}{|c|}{ Назва банку-емітента } & Галузь виробництва & Загальний обсяг облігацій, грн \\
\hline 1 & $\begin{array}{l}\text { ПАТ «Івано-Франківський } \\
\text { м’ясокомбінат» }\end{array}$ & Харчова промисловість & 450000000,00 \\
\hline 2 & $\begin{array}{l}\text { ПАТ «Тростянецький } \\
\text { м’ясокомбінат» }\end{array}$ & Харчова промисловість & 450000000,00 \\
\hline 3 & ПАТ «Ритм» & Харчова промисловість & 400000000,00 \\
\hline 4 & $\begin{array}{l}\text { ПАТ «Шкіряне } \\
\text { підприємство «Світанок» }\end{array}$ & Легка промисловість & 300000000,00 \\
\hline 5 & $\begin{array}{l}\text { Державне підприємство } \\
\text { «Донецька залізниця» }\end{array}$ & Транспорт & 300000000,00 \\
\hline \multicolumn{2}{|l}{ Джерело: складено автором на основі [5]. } \\
\hline
\end{tabular}


Наведені дані у табл. 1 свідчать, що у 2014 р. на ФБ ПФТС три компанії харчової промисловості здійснили найбільші облігаційні запозичення, при цьому сума позики кожної з них була не менше 400 млн грн. Переважно, емісія облігацій підприємствами реального сектору здійснюється з метою збільшення виробничих потужностей або реконструкції основних фондів.[5]

У 2014 році на ФБ ПФТС власні облігації розмістили 6 банків, перелік яких подано у табл. 2

Таблиця 2

\section{Емісії облігацій банків на ФБ ПФТС у 2014 році}

\begin{tabular}{|c|l|c|c|}
\hline$№$ п/п & Назва банку-емітента & Загальний обсяг облігацій, грн & Кількість серій \\
\hline 1 & Промінвестбанк & 1000000000,00 & 2 \\
\hline 2 & ВТБ Банк & 1000000000,00 & 4 \\
\hline 3 & Правекс-Банк & 500000000,00 & 2 \\
\hline 4 & Банк Креді Агріколь & 500000000,00 & 4 \\
\hline 5 & ПроКредит Банк & 400000000,00 & 1 \\
\hline 6 & Дельта Банк & 300000000,00 & \\
\hline \multicolumn{2}{|l}{ Джерело: складено автором на основі [5]. } \\
\hline
\end{tabular}

За даними табл. 2 можна зробити висновок про високу роль банків на первинному ринку корпоративних облігацій, що обумовлено значним рівнем концентрації випусків 3 боку даних фінансово-кредитних установ $(48,2 \%$ загального обсягу емісій на ФБ ПФТС у 2014 році). При цьому, головним мотивом облігаційного фінансування банків $є$ розширення ресурсної бази 3 метою збільшення активних операцій, передусім кредитування клієнтів.

Між дохідністю до погашення, купонною ставкою та ціною облігації існує взаємозв'язок, який можна описати наступним чином:

- якщо купонна ставка менша за дохідність до погашення, то ціна облігації є меншою за номінал, відповідно, на ринку облігації продаються 3 дисконтом; номіналом;

- якщо купон дорівнює дохідності, то облігації продаються за

- якщо купонна ставка більша за дохідність до погашення, тоді ціна продажу облігацій перевищує її номінал.

На рис. 3 подано розподіл дохідностей до погашення для облігацій різних емітентів, за даними інвестиційної компанії КІНТО. 


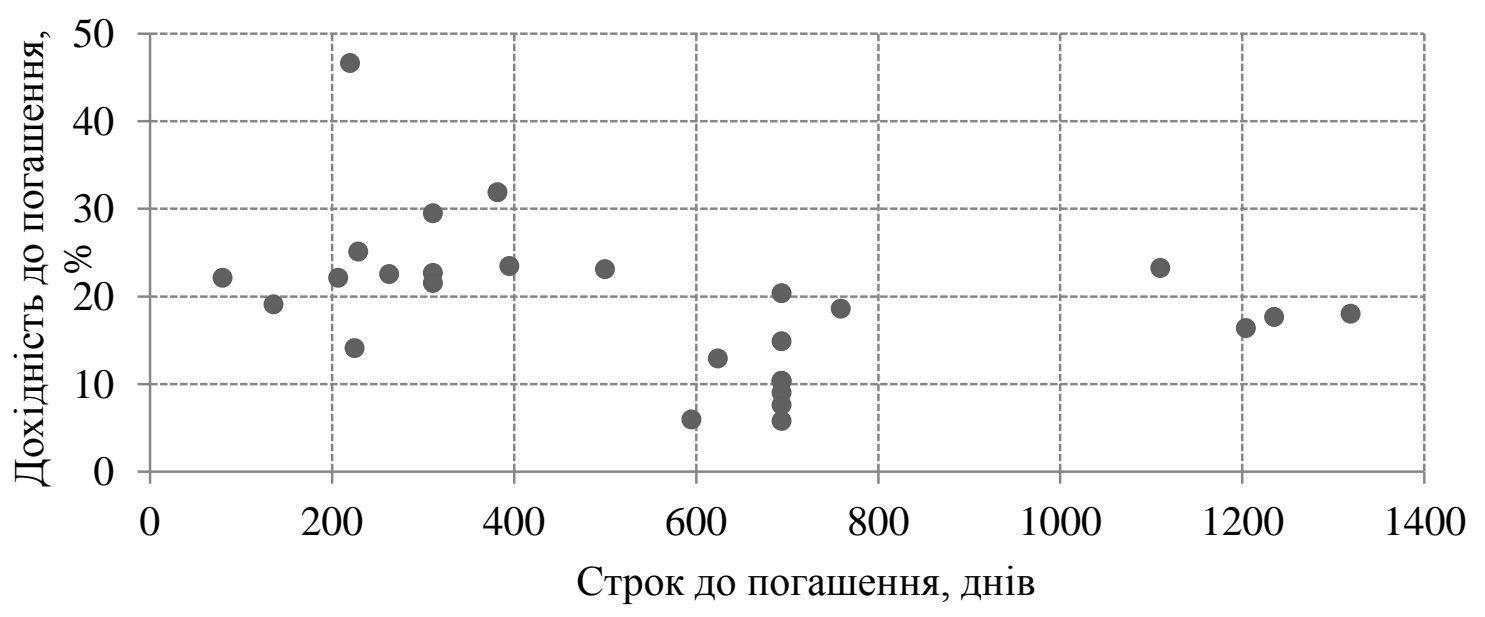

Рис. 3. Дохідність корпоративних облігацій станом на 01.01.2015 р.

Джерело: складено автором на основі [1].

На основі даних рис. 3 можна зробити висновок про значний розкид значень дохідностей за облігаціями, що пояснюється відмінностями параметрів облігаційних позик та особливостями діяльності конкретних емітентівпозичальників. Проаналізуємо високодохідні корпоративні облігації, які наведено у табл. 3.

Таблиця 3

Корпоративні облігації з високою дохідністю до погашення станом на 01.01.2015 року

\begin{tabular}{|l|c|c|c|c|}
\hline \multicolumn{1}{|l|}{ Назва емітента, серія облігацій } & $\begin{array}{c}\text { Купон, } \\
\%\end{array}$ & $\begin{array}{c}\text { Обсяг } \\
\text { емісії, } \\
\text { млн. грн. }\end{array}$ & $\begin{array}{c}\text { Строк до } \\
\text { погашення, } \\
\text { днів }\end{array}$ & $\begin{array}{c}\text { Дохідність до } \\
\text { погашення, \% }\end{array}$ \\
\hline ПАТ «Сумихімпром» (серія В) & 24 & 50 & 220 & 46,65 \\
\hline $\begin{array}{l}\text { ПАТ «АК «Богдан Моторс» } \\
\text { (серія В) }\end{array}$ & 16 & 200 & 382 & 31,89 \\
\hline $\begin{array}{l}\text { ВАТ «ЕК «Севастопольенерго» } \\
\text { (серія В) }\end{array}$ & 23 & 100 & 311 & 29,49 \\
\hline $\begin{array}{l}\text { ТОВ «Глобинський } \\
\text { м'ясокомбінат» (серія А) }\end{array}$ & 18,5 & 50 & 229 & 25,11 \\
\hline ПрАТ «Галнафтохім» (серія С) & 18 & 30 & 395 & 23,46 \\
\hline $\begin{array}{l}\text { ТОВ «Центр Фінансових } \\
\text { Рішень ФК» (серія А) }\end{array}$ & 19 & 37,5 & 1110 & 23,24 \\
\hline ТОВ «Бест» (серія А) & 16 & 25 & 500 & 23,1 \\
\hline $\begin{array}{l}\text { ПАТ «ЕК «Житомиробленерго» } \\
\text { (серія В) }\end{array}$ & 15 & 6 & 311 & 22,67 \\
\hline $\begin{array}{l}\text { ПрАТ «Донецьксталь»- } \\
\text { металургійний завод» (серія С) }\end{array}$ & 16 & 600 & 263 & 22,54 \\
\hline $\begin{array}{l}\text { ТОВ «ТПК «Омега- } \\
\text { автопоставка» (серія В) }\end{array}$ & 18 & 50 & 80 & 22,12 \\
\hline
\end{tabular}

Джерело: складено автором на основі [1,2]. 
Таким чином, облігації емітентів, які представлені у табл. 3, на фондовому ринку продаються з дисконтом. Найбільше значення доходності до погашення було зафіксовано за облігаціями серії В ПАТ «Сумихімпром» на рівні 46,65\%. Причинами значного відхилення значень купону та дохідності до погашення для даного емітента були:

— погіршення фінансового стану компанії у 2008-2013 рр. під час обігу попередньої серії облігацій компанії ;

— наявність значної заборгованості перед кредиторами та їі реструктуризація;

- невиконання умов дострокового погашення облігацій, передбачених проспектом емісії, що обумовило технічний дефолт емітента.

Наслідком цього стало зниження кредитного рейтингу емітента 3 рівня uaBB (прогноз «негативний») до рівня uaВ (прогноз «стабільний») [2]. У результаті технічного дефолту емітент підвищив купонні платежі з рівня 15\%, що було зафіксовано на момент розміщення у 2008 р., до $24 \%$, які виплачувалися інвесторам з 2009 р.

Висновки. 3 викладеного вище можна зробити висновок, що корпоративні облігації $\epsilon$ привабливішим інструментом для інвесторів порівняно 3 альтернативними борговими активами, оскільки дохідність до погашення за облігаціями підприємств зазвичай вища, що пояснюється більшим рівнем ризику при утриманні облігацій компаній у портфелі активів. Проте, для емітента дане джерело фінансування може виявитися дорожчим за банківські кредити. Незважаючи на це, компанії у 2014 році здійснювали активне залучення фінансових ресурсів саме шляхом випуску облігацій.

Наукова новизна дослідження полягає у систематизації характеристик інструментів боргового фінансування і на іiі основі, порівнянні джерел фінансування для компаній-емітентів на вітчизняному фондовому ринку та аналізі методу залучення фінансових ресурсів шляхом випуску облігацій на прикладі українських компаній у 2014 році.

Теоретична значимість дослідження полягає у встановленні зв'язку між дохідністю до погашення, купонною ставкою та ціною облігації, що в подальшому дає можливість для раціонального вибору інструментів залучення зовнішніх коштів.

Практична цінність дослідження полягає у виявленні причин значного відхилення значень купону та дохідності до погашення для українських підприємств-емітентів у 2014 році, що є підгрунтям до оцінювання тенденцій і напрямків оптимізації боргового фінансування.

Подальшого дослідження і обгрунтування потребує процес боргового фінансування в Україні та його вплив на розвиток вітчизняних компаній та фінансових структур. 


\section{Література:}

1. Офіційний сайт інвестиційної компанії «КІНТО»/ [Електронний ресурс]. - Режим доступу: http://www.kinto.com.

2. Офіційний сайт Інформаційного агентства «Cbonds.Info» / [Електронний ресурс]. Режим доступу: http://www.cbonds.info.

3. Офіційний сайт Національного рейтингового агентства «Рюрік» / [Електронний pecypc]. - Режим доступу : http://rurik.com.ua.

4. Бельзецкий А. Риски корпоративних облигаций / А.Бельзецкий //Банковский вестник / [Електронний ресурс]. - Режим доступу: www.nbrb.by/bv/narch/405/6.pdf.

5. Офіційний сайт фонової біржі «ПФТС» / [Електронний ресурс]. - Режим доступу: http://www.pfts.com.

6. М. О. Боровікова Фінансування підприємства за допомогою довгострокового боргу / [Електронний ресурс]. - Режим доступу: http://www.economy.nayka.com.ua/?op=1\&z=4187

7. Про цінні папери та фондовий ринок: Закон України від 23 лютого 2006 року № 3480IV / [Електронний ресурс]. - Режим доступу: http://zakon.rada.gov.ua.

8. Шелудько В.М. Фінансовий ринок / В.М. Шелудько. - К.: Знання, 2002.- 535c.

9. Brealey R.A. Principles of corporate finance: Seventh edition / Richand A. Brealey, Stewart C. Myers. - USA, Boston: McGraw-Hill Irwin, 2003. - 1011 p.

10. Зачосова Н.В. Механізм створення Фонду гарантування інвестицій як суб'єкта захисту економічної безпеки компаній з управління активами та торговців цінними паперами в Україні / Н.В. Зачосова// Економічний часопис XXI. - 2010 . - № 5-6. - C.18-23. 